\title{
Factoring scales of spatial and temporal variation in fish abundance in a subtropical estuary
}

\author{
A. M. Garcia ${ }^{1, *, * *}$, J. P. Vieira ${ }^{1}$, K. O. Winemiller ${ }^{2}$, L. E. Moraes ${ }^{1}$, E. T. Paes ${ }^{3, * *}$ \\ ${ }^{1}$ Instituto de Oceanografia, Laboratório de Ictiologia, Universidade Federal de Rio Grande (FURG), Caixa Postal 474 , \\ Rio Grande, RS 96201-900, Brazil \\ ${ }^{2}$ Department of Wildlife and Fisheries Sciences, Texas A\&M University, College Station, Texas 77843-2258, USA \\ ${ }^{3}$ Instituto de Sócio Ambiental e dos Recursos Hídricos, Universidade Federal Rural da Amazônia (UFRA), Caixa Postal 917, \\ Belém, PA 66077-530, Brazil
}

\begin{abstract}
We employed a new approach linking multivariate and time series analyses to identify common versus unique spatiotemporal components of abundance variation of marine spawning fishes recruiting into a subtropical Western Atlantic estuary. Based on a $10 \mathrm{yr}$ standardized monthly data set, we also investigated patterns of association for local and regional factors with annual and inter-annual variation in abundance of 5 dominant marine estuarine-dependent fishes. The total amount of variation in fish abundance explained by environmental variables was $22.4 \%$. After factoring out shared spatiotemporal variation $(0.8 \%)$, our analysis showed that temporal components had an almost 5-fold greater contribution $(28.0 \%)$ than spatial components $(6.4 \%)$ in explaining the variation in abundance of the 5 species. Most of the variation across the temporal scale (58.5\%) was associated with annual (from 0.5 to $1.3 \mathrm{yr}$ ) rather than multi-year oscillations ( $>2 \mathrm{yr}$ ). Such annual patterns were probably associated with adaptations of marine estuarine-dependent fishes for exploiting predictable pulses in seasonal productivity typically found in subtropical estuaries. In contrast, inter-annual variation in abundance occurring at a scale of 3 to 7 yr could be attributed to rainfall anomalies associated with El Niño Southern Oscillation (ENSO) events, whereas those occurring at a scale of $2 \mathrm{yr}$ could be influenced by the Southern Annular Mode (SAM). Our findings corroborate the hypothesis that prevalent annual patterns of variation in the abundance of marine estuarine-dependent fishes are associated with predictable productivity pulses linked to the annual temperature regime, whereas inter-annual variations in fish abundance are associated with the influence of large-scale climatic phenomena.
\end{abstract}

KEY WORDS: Time-series analyses $\cdot$ Partitioning variation $\cdot$ Estuarine-dependent species $\cdot$ Mullet . Whitemouth croaker $\cdot$ Argentine menhaden $\cdot$ Patos Lagoon estuary $\cdot$ Brazilian-LTER

\section{INTRODUCTION}

Estuarine fish abundance shows high intra- and inter-annual variability across spatial and temporal scales (e.g. Power et al. 2000, Garcia et al. 2004a, James et al. 2008). Such modes of variation are especially strong in marine migrant fishes that spawn in the sea and use estuarine areas as nursery grounds (Vieira \& Scalabrin 1991, Able 2005, Akin et al. 2005). Abundance of marine estuarine-dependent fishes often varies widely across coastal salinity gradients, with postlarvae entering deeper waters and juveniles dispersing within shallow waters $(<1.5 \mathrm{~m})$ along the estuarine margins (Martino \& Able 2003, Greenwood 2007, Sosa-López et al. 2007, Upchurch \& Wenner 2008, González-Castro et al. 2009). Juveniles and/or adults of certain marine migrant fishes move several kilometers up the salinity gradient into oligohaline waters near the boundaries with freshwater inflows, or even into the main channels of rivers (Martino \& 
Able 2003). Abundance of marine migrant fishes within estuarine habitats may change greatly over time scales that range from days, months or years (Whitfield 1996). Most studies of abundance dynamics of estuarine fishes have focused on seasonal (e.g. Chao et al. 1985, Ambrose \& Meffert 1999, Gordo \& Cabral 2001, Upchurch \& Wenner 2008, Herrell \& Methven 2009, Love et al. 2009, Plavan et al. 2010) and, to a lesser extent, inter-annual scales of variation (e.g. Power et al. 2000, Garcia et al. 2004a, Martinho et al. 2009, Reum et al. 2011). For instance, dry and wet episodes associated with cold and warm El Niño Southern Oscillation (ENSO) events have been shown to play an important role in structuring fish assemblages on an inter-annual basis in subtropical estuaries of the Southwest Atlantic Ocean (Garcia et al. 2001, 2003a, 2004a).

However, prior studies of estuarine fish abundance across spatiotemporal scales have not clearly addressed the issue of multicolinearity between these scales of variation. There may be redundancy in the variation explained by temporal and spatial variables (Bertolo \& Magnan 2006, Peres-Neto 2006) that has not been taken into account in previous studies on spatiotemporal patterns in the abundance of fishes occurring in estuaries (Martino \& Able 2003, PérezRuzafa et al. 2007, González-Castro et al. 2009). In this paper, we employed a 4-step analysis using Canonical Correspondence Analysis (CCA) and partial CCA to partition the variation in the abundance of 5 estuarine-dependent fishes (mullets Mugil liza, M. gaimardianus and M. curema, Argentine menhaden Brevoortia pectinata, and whitemouth croaker Micropogonias furnieri) explained by independent variables into different components (Borcard et al. 1992). This approach factors out common and unique contributions of spatial and temporal components when modeling variation in fish abundance (Borcard et al. 1992, Peres-Neto 2006), yielding a more accurate representation of patterns and insights into potential causal factors.

In addition, based on a $10 \mathrm{yr}$ data set of monthly abundances, we employed a new analytical approach linking multivariate and time series analyses to investigate patterns of temporal variation of the 5 marinespawning fishes recruiting into a subtropical estuary. This continuous and standardized time series of marine estuarine-dependent fishes, probably the largest available in the estuaries emptying into the southwestern Atlantic Ocean, allowed us to address 3 basic questions. What are the most prominent patterns of variation in abundance among marine estuarine-dependent fishes in subtropical estuaries? Are these patterns associated primarily with temporal or spatial dimensions? How do local (temperature, salinity) and regional (rainfall) physicochemical factors correlate with temporal patterns of variation observed at different scales? We evaluate the hypothesis that annual patterns of variation in abundance of new recruits are linked to temperature regime, whereas patterns of inter-annual variation are associated with occurrence of larger-scale climatic phenomena.

\section{MATERIALS AND METHODS}

\section{Study area}

Patos Lagoon $\left(32^{\circ} \mathrm{S}, 52^{\circ} \mathrm{W}\right)$ is located along the coastal plain of Rio Grande do Sul in southern Brazil. It is the largest choked lagoon in the world, measuring $250 \mathrm{~km}$ long and $60 \mathrm{~km}$ wide and covering an area of $10360 \mathrm{~km}^{2}$ (Fig. 1). According to Kjerfve (1986), choked lagoons have a single entrance channel and small ratios of entrance-channel cross-sectional area to lagoon surface area. The brackish area is restricted to the southern portion of the Patos Lagoon (ca. 10.0\% of total area). This lagoon is connected to the ocean by a single inlet about $4 \mathrm{~km}$ long and $740 \mathrm{~m}$ wide at the mouth (Fig. 1). The lagoon's drainage basin covers $201626 \mathrm{~km}^{2}$ (Asmus 1997). Wind patterns and fluvial discharge control circulation, salinity distribution, and water levels. Seasonal freshwater discharge varies considerably (47 to $30300 \mathrm{~m}^{3} \mathrm{~s}^{-1}$ ), and during El Niño years, runoff greatly exceeds average values. Tidal influence in the estuary is minimal (mean tidal amplitude of $0.47 \mathrm{~m}$ ). Winds are predominantly NE to SW in the region (Möller et al. 2001). Sand is the dominant fraction in the shallower waters $(<1.5 \mathrm{~m})$ of the estuary, whereas the proportion of silt and clay increases with depth (Calliari et al. 1977). Vegetated habitats are commonly found within the estuary, especially saltmarsh plants such as Spartina densiflora and $S$. alterniflora and widgeon grass Ruppia maritima, which forms extensive meadows during spring and summer (Costa et al. 1997).

The ichthyofauna of the Patos Lagoon Estuary is composed of about 110 species, but only a few are frequent and abundant throughout the year (Chao et al. 1985, Vieira et al. 2010). A few species complete their entire life cycle within this estuary, such as the one-sided livebearer Jenynsia multidentata (Garcia et al. 2004b) and the silverside Odontesthes argentinensis (Bemvenuti 1987), whereas others spawn in the sea and their young-of-the-year (YOY) recruit into the estuary, where they remain until maturation 

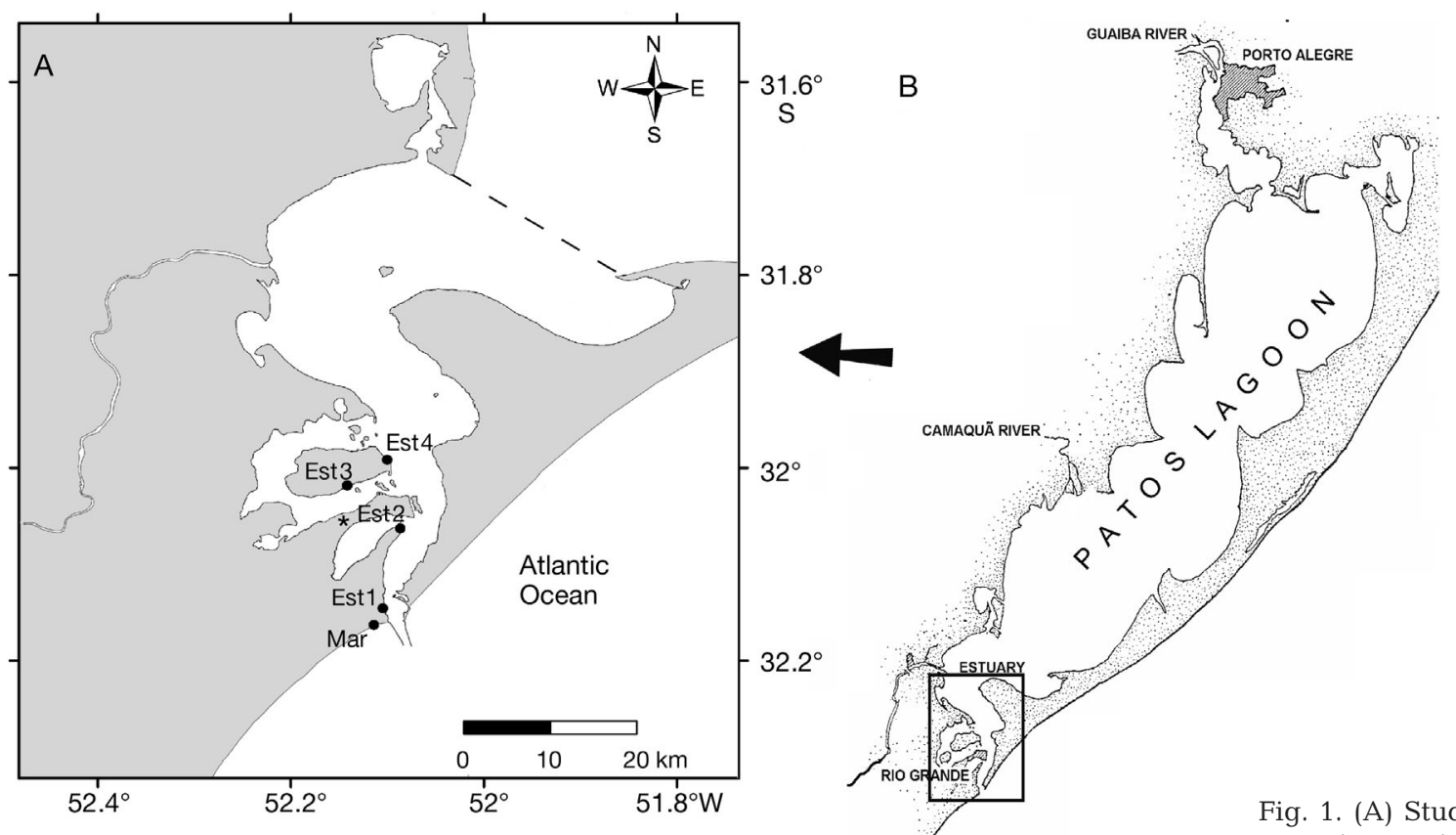
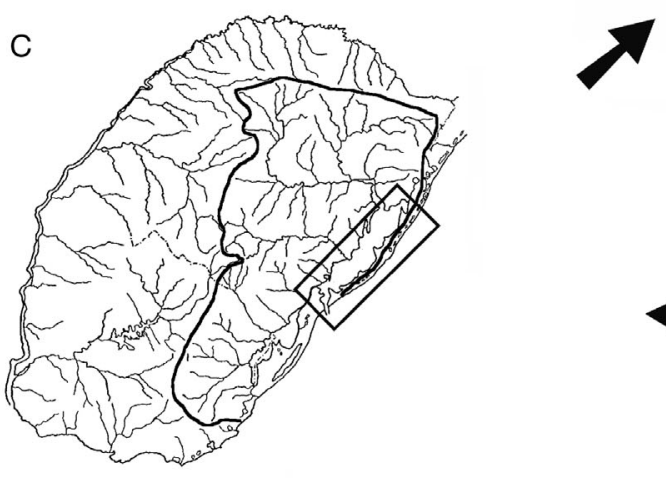

and then return to the sea to spawn and complete their life cycles (Vieira \& Castello 1997). Some of these marine estuarine-dependent species (e.g. mullets and whitemouth croaker) dominate the biomass of industrial and artisanal fisheries along the southern Brazilian coast (Haimovici et al. 1996, Reis \& D'Incao 2000). For this study, we chose the most abundant marine estuarine-dependent fishes occurring in the Patos Lagoon Estuary and its adjacent marine area: the Argentine menhaden, whitemouth croaker, and the 3 species of mullets occurring in this estuary. These species account for $62.0 \%$ of the total abundance of juvenile fishes recruiting annually in this estuary (Vieira et al. 2010).

\section{Field collections and sample procedures}

Sampling field stations were located in the shallow waters of the Patos Lagoon Estuary (mean depth < $1.5 \mathrm{~m}$ ), where abundant marine estuarine-dependent
Fig. 1. (A) Study area in the estuarine section of (B) Patos Lagoon, and $(\mathrm{C})$ its drainage basin (black line), which covers an area of ca. 201626 $\mathrm{km}^{2}$, located in (D) Southern Brazil. (•) Sampling beach stations at the marine adjacent area (Mar) and inside the estuarine zone (Est1, Est2, Est3, Est4). (dashed line) Usual boundary between estuarine and limnetic zones. (*) Meteorological station at Rio Grande city

fishes can be efficiently sampled with a seine net (Fig. 1). Fish were sampled using a $9 \mathrm{~m}$ beach seine (13 $\mathrm{mm}$ bar mesh in the wings and $0.5 \mathrm{~mm}$ mesh in the $3 \mathrm{~m}$ center section) that was pulled to cover an area of about $60 \mathrm{~m}^{2}$ during each haul. Five hauls were made monthly (usually in the first week of each month) at each beach station from August 1996 to January 2007. Specimens were preserved in $10 \%$ formalin and later identified, counted and measured for total length (TL) to the nearest $\mathrm{mm}$. Concomitant with fish sampling, we measured the water temperature and salinity at each site. We obtained monthly rainfall data from 1996 to 2007 from the nearby meteorological station of the Federal University of Rio Grande (Fig. 1).

\section{Statistical procedures}

Relationships between fish species' abundance and spatiotemporal modes of variation were analyzed with 
CCA using the software package CANOCO (ter Braak 1986, ter Braak \& Šmilauer 2002). We used a Monte Carlo permutation test (no. of permutations = 9999) to assess the statistical significance of these relationships. When the length of first factorial axis obtained by Detrended Correspondence Analysis (DCA) is greater than 3 standard deviations, it is more appropriate to use a unimodal method (CCA) instead of linear models such as Redundancy Analysis (RDA, ter Braak \& Šmilauer 2002). According to this criterion, CCA was chosen because it assumes unimodal relationships between dependent and independent variables (Lepš \& Šmilauer 2003).

Because temporal variation can show multicolinearity across spatial scales, there can be a degree of redundancy in the variation explained by temporal and spatial variables (Bertolo \& Magnan 2006, PeresNeto 2006). To account for this potential redundancy, we used a 4-step analysis using CCA and partial CCA (i.e. CCA with covariables) to partition the variation in fish abundance explained by independent variables into different components (see Borcard et al. 1992 and Legendre 2008 for further details of computation). This method allows factoring of common and unique contributions of independent components when explaining variation in the dependent variable (Borcard et al. 1992), resulting in a better understanding of the influences of both groups of independent variables (Peres-Neto 2006).

Four adjusted fractions (Peres-Neto et al. 2006) were obtained using this method. First, we obtained the unique or 'pure' variation in species abundance explained by space (i.e. after controlling the variation related to temporal scale). According to Borcard et al. (1992), this spatial effect, in general terms, may reflect contagious biological processes (e.g. dispersal, habitat preference) that have no relation with the temporal variables per se. Second, we calculated the equivalent unique or 'pure' contribution of the temporal component (after controlling for spatial effect). Third, we obtained the variation in fish abundance that cannot be uniquely assigned to spatial or temporal scales (i.e. colinearity or shared variation). Finally, we estimated the undetermined variation in fish species abundance that is not explained by spatial coordinates or by temporal independent variables (Borcard et al. 1992, Peres-Neto 2006).

We applied this partition variation method to determine which scale (spatial or temporal) explains more variation in fish species abundance, followed by a detailed description of how fish abundance varied for the scale identified as being most important in struc- turing the data set. Fish species abundance in catch per unit effort (CPUE) populated the dependentvariable matrix, and spatial and temporal descriptor variables populated sets of independent-variable matrices.

There are different ways to represent space (or time) in multivariate analyses, including use of polynomials of geographic coordinates and dummy variables (binary scores for presence or absence) (Legendre \& Legendre 1998). However, these methods are sufficient to represent only coarse scales of variation. To better represent spatial and temporal variation at finer scales, Borcard \& Legendre (2002) proposed a new technique called principal coordinates of neighbor matrices (PCNM). Starting from a matrix of Euclidean distances among objects representing sample sites or time intervals, a truncated matrix of neighbor distance is produced. This matrix is used to compute principal coordinates in which positive eigenvectors represent Euclidean components of the neighborhood relationships of the truncated matrix. These principal coordinates represent spatial or temporal descriptors and can be used post hoc as explanatory (independent) variables in multivariate analyses (see Borcard \& Legendre 2002 for further details). This method was originally proposed to depict spatial structure, but it also can be used to explore temporal structure (Peres-Neto 2006). Thus, PCNM analysis is analogous to a spectral decomposition of spatial and temporal relationships among sampling sites or temporal units (e.g. months), creating variables that correspond to all spatial and temporal scales that can be perceived in a given data set (Borcard et al. 2004, Peres-Neto 2006). PCNM eigenvectors (herein referred to as 'temporal descriptors') were computed using the SpaceMaker 2 software (Borcard \& Legendre 2004). We used a value of 0.092 as the truncation point in the distance matrix of latitude and longitude coordinates corresponding to our 5 irregularly distributed sampling sites, and 3 spatial descriptors were generated. For the regularly distributed time scale, we used $1.0 \mathrm{mo}$ as the truncation value in our 126 sample-months matrix, and 85 temporal descriptors were generated. Previously, we tested distinct forms of space and time representations (dummy, geographic coordinates, polynomial, PCNM) to determine which ones explained the greatest amount of variation in the dependent variables. Dummy variables performed best for sampling sites, and temporal descriptors were best for collection periods; these spatial (dummy) and temporal (PCNM) descriptors were used as 2 sets of independent variables in CCA. 
We employed CCA bi-plot diagrams to depict the principal relationships between dependent (fish species abundance) and independent (spatial, temporal) variables (ter Braak \& Šmilauer 2002). In this ordination diagram, the relative importance of independent variables in explaining variability in species abundance is indicated by the length and angle of vectors in bi-plots. The angle and length of the vector relative to a given canonical axis reveals the magnitude of the variable's correlation with that axis, effectively revealing its relative influence in producing the gradient modeled by the axis. The position of a species on a given canonical axis reveals its association with the gradient (i.e. increasing abundance in response to the gradient).

A forward selection procedure for CCA was employed in order to select, for inclusion in the ultimate model, only those independent variables that were statistically significant $(p<0.05 ; p<0.006$ following Bonferroni correction) in explaining variation in fish abundance. We used $t$-value bi-plots with Van Dobben circles to evaluate the relationship between individual explanatory variables and fish species abundance (ter Braak \& Looman 1994). These ordination diagrams are built based on $t$-values of canonical coefficients from CCA and are useful to identify significant pair-wise positive and negative correlations between dependent and independent variables (Lepš \& Šmilauer 2003). In the Van Dobben diagrams, those species with arrow-heads ending inside the circles have statistically significant pair-wise relationship with the assigned explanatory variable ( $t$-values regression coefficient between -2 and +2 ), where gray and white circles denote positive and negative relationships, respectively. Those fishes with arrow-heads ending out of the circles lack statistically significant association with the explanatory variable analyzed ( $t$-value $<-2$ or $>+2$ ).

Finally, relationships between fish species abundance and environmental variables (water temperature, salinity, rainfall) were analyzed with a CCA (ter Braak 1986). We used the same basic parameters (e.g. significance level) and the software used for the partial CCAs explained above.

\section{RESULTS}

\section{Overall abundance patterns}

A total of 206801 individuals of the 5 studied fish species were caught throughout the 126 mo of standardized sampling. Most individuals (76.1\%) were

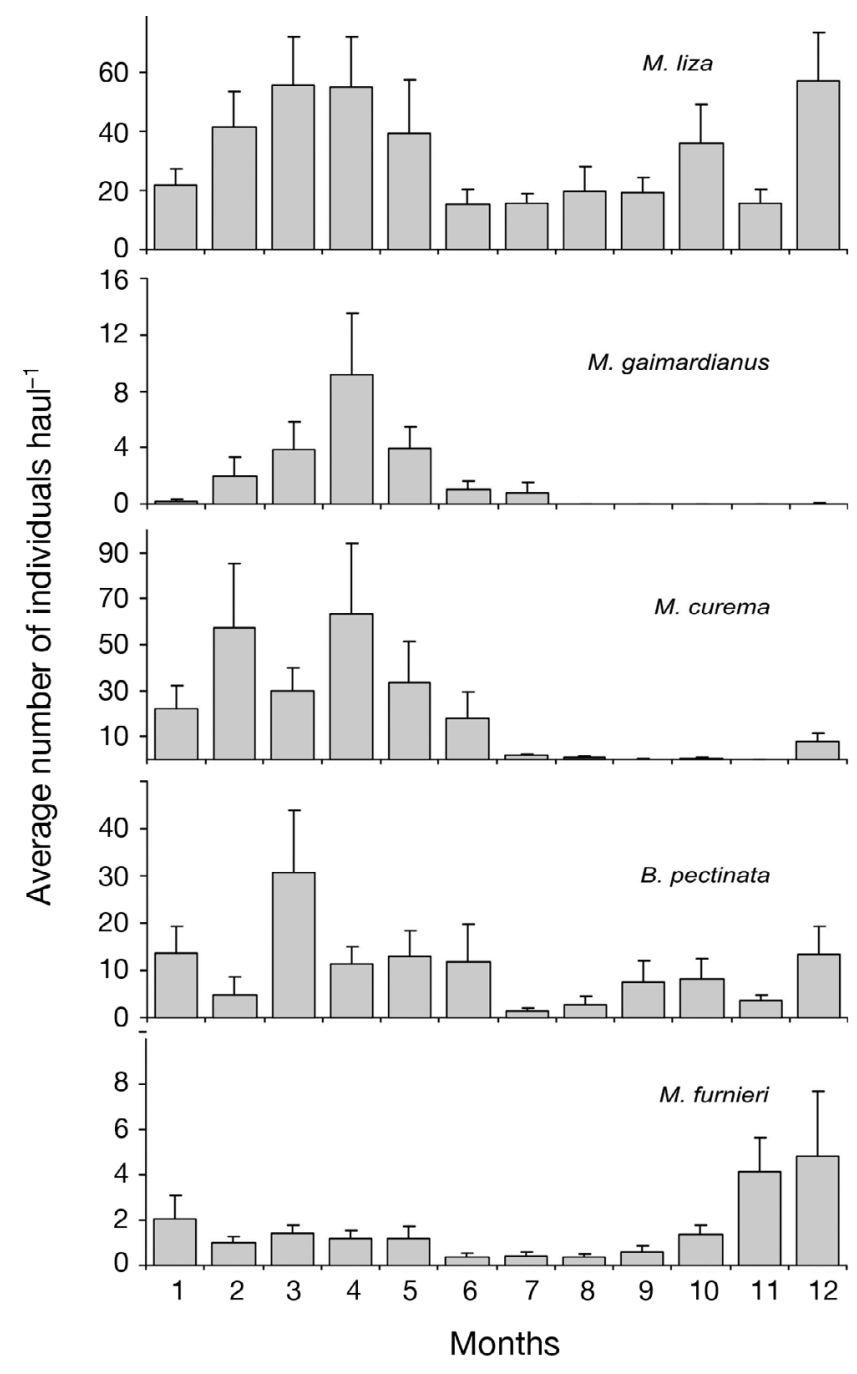

Fig. 2. Mugil liza, M. gaimardianus, M. curema, Brevoortia pectinata and Micropogonias furnieri. Intra-annual variation of the average (+SE) number of individuals per haul, determined from the natural logarithm of catch per unit effort (ln CPUE +1 ) for the 5 fish species collected (3 mullet species, Argentine menhaden and whitemouth croaker). Months from January (1) to December (12) are shown on $x$-axis

captured inside the estuary, especially in the 2 sites closest to the estuary's mouth $(21.4 \%$ at Est1 and $30.4 \%$ at Est2, Fig. 1).

The 3 mullet species comprised $83.2 \%$ of the total catch; Mugil liza alone represented $54.6 \%$ of the overall catch. The Argentine menhaden and whitemouth croaker constituted 14.9 and $2.0 \%$ of the catch, respectively. All species revealed marked intra- and inter-annual variation in their relative abundance (Figs. 2 \& 3, respectively) and, with the exception of mullets $M$. gaimardianus and $M$. curema, occurred year-round in the study area. 


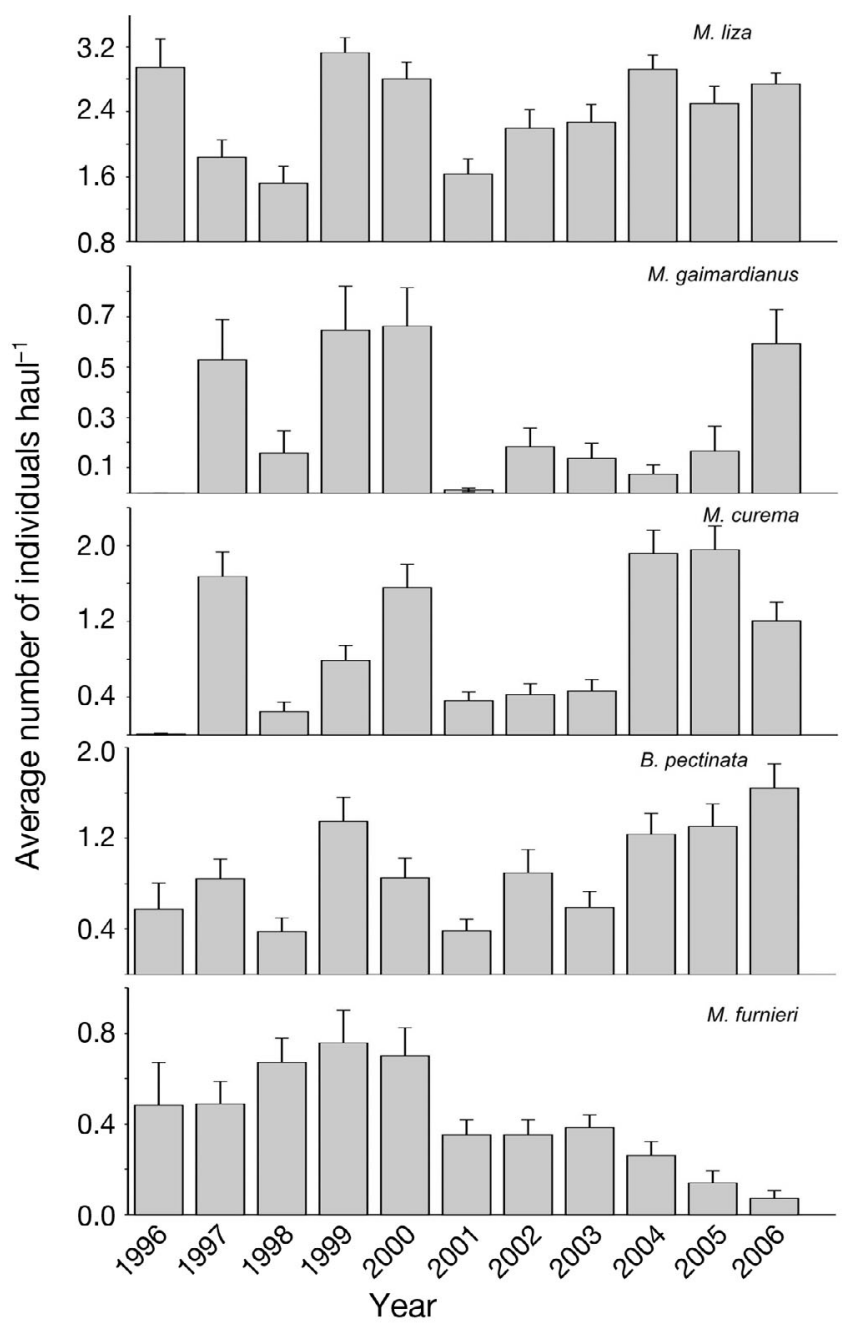

Fig. 3. Mugil liza, M. gaimardianus, M. curema, Brevoortia pectinata and Micropogonias furnieri. Inter-annual variation of the average (+SE) number of individuals per haul, determined from the natural logarithm of catch per unit effort (ln CPUE +1 ) for the 5 fish species collected ( 3 mullet species, Argentine menhaden and whitemouth croaker)

\section{Species abundance correlations with environmental factors}

Fig. 4 shows average monthly variation in rainfall, salinity and water temperature in the study site from 1996 to 2007 . Water temperature revealed a seasonal pattern of fluctuation, with lowest values $\left(11.5^{\circ} \mathrm{C}\right)$ occurring during austral winter months (July and August) and highest average values $\left(26.5^{\circ} \mathrm{C}\right)$ during summer months (December to February). Salinity also showed a tendency towards lower values $(\sim 5)$ during colder months and higher values $(\sim 25)$ during warmer months. However, in contrast with the regular pattern observed for temperature, salinity showed
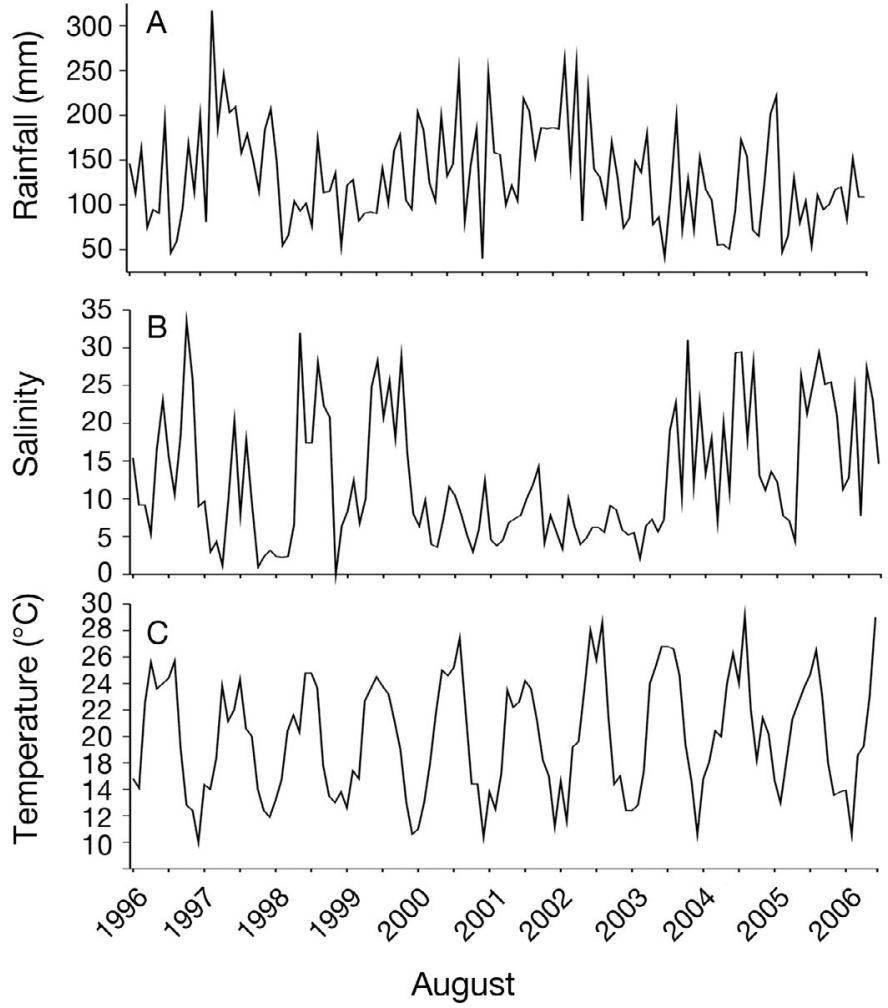

Fig. 4. (A) Total rainfall (mm), and average values of (B) salinity and $(\mathrm{C})$ water temperature $\left({ }^{\circ} \mathrm{C}\right)$ in the estuarine area of Patos Lagoon from August 1996 to January 2007. $X$-axis ticks correspond to August and January of each year

strong intra- and inter-annual variation with different patterns observed in different years. For instance, in some years (e.g. 1997-1998 and 2000-2003) there was a predominance of near-zero salinity recordings, whereas in others (e.g. 1999-2000 and 2004-2006) salinity achieved higher values (>25) (Fig. 4).

CCA using rainfall, temperature and salinity as environmental variables explained $22.4 \%$ of the variation in fish abundance during the $10 \mathrm{yr}$ study period, with the first and second axes accounting for $96.1 \%$ of total variation (Fig. 5). Relationships between species abundances and environmental variables influencing these axes were statistically significant $(p<$ $0.05)$, with salinity and temperature accounting for a greater fraction of the explained variation $(75.3 \%)$ than rainfall.

According to the CCA results, the 5 fish species had distinct responses to temperature, salinity and rainfall gradients over the 10 yr period (Fig. 5). Salinity and rainfall gradients were inversely correlated and fish abundances showed opposite responses to these variables. Abundance of the mullets Mugil gaimardianus and M. curema and Argentine men- 


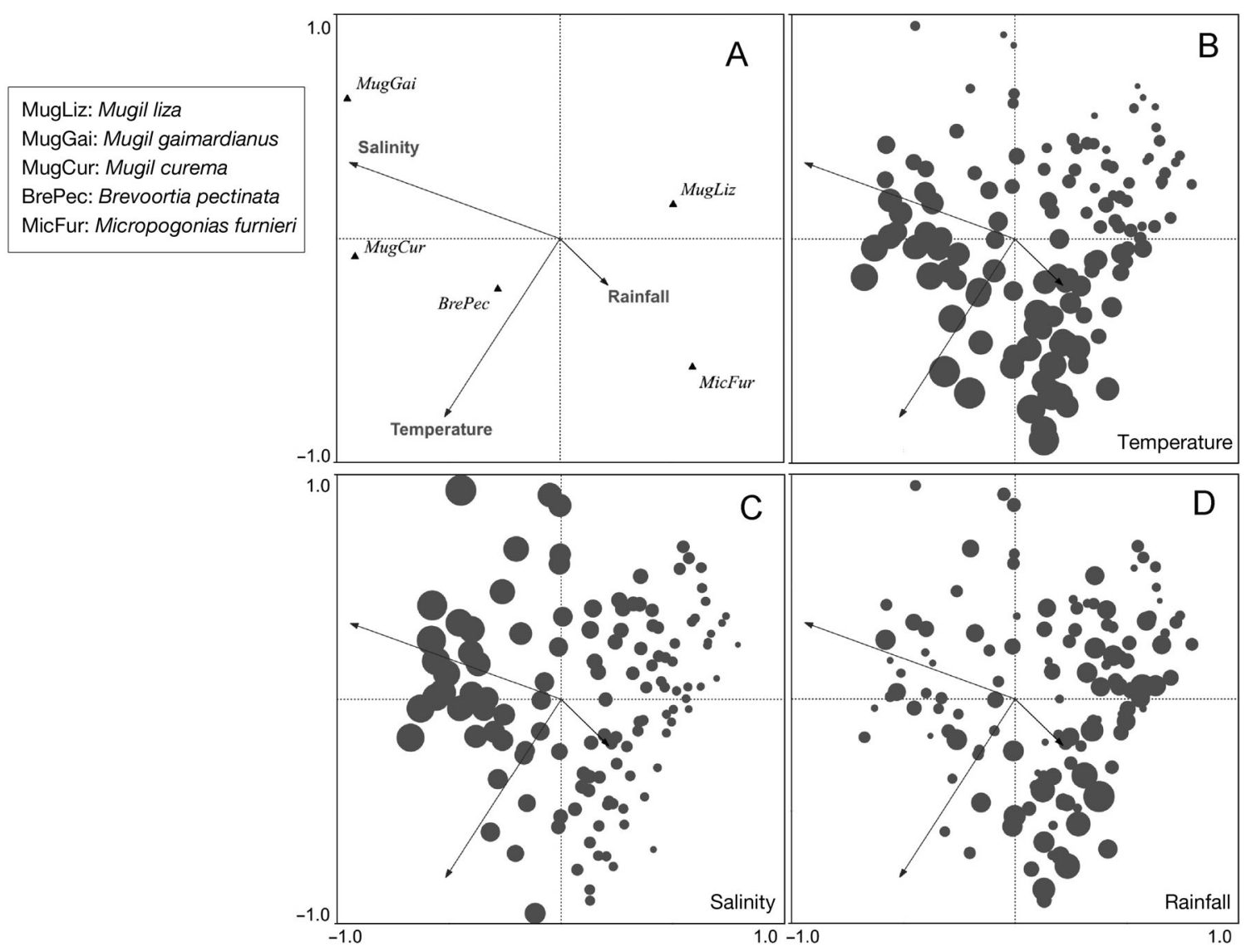

Fig. 5. Canonical Correspondence Analysis (CCA) ordination plots showing (A) association of fish species with temperature, salinity and rainfall gradients, where each axis is represented by its score (plotted) and correlation between environmental variables and axes is represented by the length and angle of arrows, and association of samples with (B) temperature, (C) salinity and (D) rainfall gradients. The diameter of each circle is proportional to the observed values of each parameter in each month in each sample site

haden were positively correlated with salinity and negatively correlated with rainfall. In contrast, the mullet M. liza and the whitemouth croaker were more abundant during intervals of low salinity and high rainfall. Abundances of mullet $M$. curema and Argentine menhaden were positively associated with temperature, whereas mullet $M$. liza was more abundant during cooler periods (Fig. 5).

\section{Partitioning of the spatiotemporal components of variation in fish abundance}

Analysis of fish abundance variation across spatiotemporal scales using CCA and partial CCA revealed that variation in species abundance was almost 5 -fold higher across the temporal than the spatial scale (Table 1). Differences in species abundance across estuarine sites explained by the spatial descriptors (after controlling the variation related to temporal scale) were only $6.4 \%$. In contrast, the variation across the $10 \mathrm{yr}$ period explained by the temporal descriptors (after controlling the variation related to spatial scale) was $28.0 \%$. Interaction, or colinearity, between spatial and temporal scales was minimal $(0.8 \%)$, but a large fraction of fish abundance variation $(64.8 \%)$ could not be explained by any spatial or temporal components estimated in this study (Table 1).

Spatial differences in fish species abundance occurred mainly between sites near the estuary mouth and those located in the estuary's interior (Est2, Est3) (Fig. 6). The location Est4 was not included in the CCA analysis because it did not make a significant contribution to the model according to the forward selection procedure. Abundance of mullets was strongly associated with sites near the channel that connects the estuary to the ocean, particularly Mugil 
Table 1. Overall results of the 4 partial Canonical Correspondence Analyses (CCAs) performed to partition the variation in abundance of the 5 dominant marine estuarine-dependent fishes into (a) pure space (6.4\%), (b) space and time combined (colinearity) $(0.8 \%)$, (c) pure time $(28.0 \%)$ and $(\mathrm{d})$ undetermined variation $([100-(\mathrm{a}+\mathrm{b}+\mathrm{c})]=100-35.2=64.8 \%)(\mathrm{sensu}$ Borcard et al. 1992). Total inertia in all CCA was 0.987. Significance based on Monte Carlo permutation (n = 9999) test for the first and all axes. ${ }^{*} \mathrm{p}<0.001$

\begin{tabular}{|c|c|c|c|c|c|c|}
\hline \multirow{2}{*}{ Axes } & \multicolumn{4}{|c|}{ Eigenvalues } & \multirow[t]{2}{*}{ Trace } & \multirow{2}{*}{$\%$ variance explained } \\
\hline & 1 & 2 & 3 & 4 & & \\
\hline Species vs. Space & $0.040^{*}$ & 0.017 & 0.010 & 0.003 & $0.071^{*}$ & 7.2 \\
\hline Species vs. Time & $0.162^{*}$ & 0.053 & 0.045 & 0.023 & $0.284^{*}$ & 28.8 \\
\hline Species vs. Space with Time as covariate & $0.050^{*}$ & 0.018 & 0.009 & 0.002 & $0.063^{*}$ & 6.4 \\
\hline Species vs. Time with Space as covariate & $0.165^{*}$ & 0.053 & 0.049 & 0.024 & $0.276^{*}$ & 28.0 \\
\hline
\end{tabular}

Table 2. Thirteen (out of 85 ) eigenvectors obtained by the principal coordinates of neighbor matrices (PCNM) that were considered as significant ( $\mathrm{p}$ 0.006, after Bonferroni's correction and the Forward Selection procedure) for patterns in variation of fish abundance of 5 marine estuarine-dependent fish species based on (A) annual and (B) inter-annual time scales. LambdaA (conditional effect) accounts for the amount of variability explained by the variable (eigenvector), whereas LambdaA (\%) is the percentage related to the total inertia (0.284) explained by all eigenvectors

\begin{tabular}{|c|c|c|c|c|c|c|}
\hline Eigenvector & F-ratio & $\mathrm{p}$-value & LambdaA & $\begin{array}{c}\text { LambdaA } \\
(\%)\end{array}$ & $\begin{array}{r}\text { Scale of } \\
(\mathrm{mo})\end{array}$ & $\begin{array}{l}\text { variation } \\
\text { (yr) }\end{array}$ \\
\hline \multicolumn{7}{|c|}{ (A) Annual variation patterns (0.5 to $1.3 \mathrm{yr}$ ) } \\
\hline PC-41 & 6.71 & 0.004 & 0.009 & 3.2 & 6.0 & 0.5 \\
\hline PC-25 & 8.48 & 0.001 & 0.011 & 3.9 & 9.7 & 0.8 \\
\hline PC-21 & 30.82 & 0.001 & 0.047 & 16.5 & 11.4 & 0.9 \\
\hline PC-23 & 7.23 & 0.002 & 0.009 & 3.2 & 10.5 & 0.9 \\
\hline PC-20 & 37.09 & 0.001 & 0.059 & 20.8 & 12.0 & 1.0 \\
\hline PC-19 & 16.57 & 0.001 & 0.023 & 8.1 & 12.6 & 1.0 \\
\hline PC-15 & 6.22 & 0.001 & 0.008 & 2.8 & 15.7 & 1.3 \\
\hline \multicolumn{7}{|c|}{ (B) Inter-annual variation patterns ( $>2 \mathrm{yr}$ ) } \\
\hline PC-8 & 9.03 & 0.001 & 0.012 & 4.2 & 28.0 & 2.3 \\
\hline PC-7 & 8.31 & 0.001 & 0.011 & 3.9 & 31.5 & 2.6 \\
\hline PC-5 & 13.84 & 0.001 & 0.019 & 6.7 & 42.0 & 3.5 \\
\hline PC-3 & 6.4 & 0.003 & 0.008 & 2.8 & 63.0 & 5.2 \\
\hline PC-2 & 18.92 & 0.001 & 0.026 & 9.2 & 84.0 & 7.0 \\
\hline PC-1 & 24.23 & 0.001 & 0.035 & 12.3 & 126.0 & 10.5 \\
\hline
\end{tabular}

$28.8 \%$ ) in fish species abundance. For example, the temporal descriptor PC-20, which depicted fluctuation occurring in a temporal scale of $1 \mathrm{yr}$, accounted for $20.8 \%$ of explained variation in fish abundance (Table 2 , Fig. 7).

Correlations of individual species abundances with these annual and inter-annual descriptors varied considerably, and this can be observed in the $t$-value bi-plots with Van Dobben diagrams that show statistically significant pair-wise relationships between species and selected explanatory variables (Fig. 8). For instance, the mullets Mugil gaimardianus and $M$. curema were positively correlated with PC-20 (1 yr), whereas mullet $M$. liza and whitemouth croaker were negatively correlated with these same temporal descriptors (Fig. 8). These opposite correlation patterns were associated with distinct peaks of recruitment of gaimardianus at Mar and M. liza and M. curema at Est1. In contrast, the Argentine menhaden and the whitemouth croaker tended to be more abundant at sites in the middle region of the estuary (Est2, Est3) (Fig. 6).

Forward selection procedure identified 13 (out of 85) variables as significant temporal descriptors (Table 2), and these were included in the partial CCA as independent variables. These temporal descriptors (PCNM) revealed variation at 2 main scales: annual (0.5 to $1.3 \mathrm{yr}$ ) and inter-annual (2.3 to $10.5 \mathrm{yr}$ ) (Table 2). Seven annual and 6 inter-annual temporal descriptors accounted for 58.5 and $39.1 \%$, respectively, of total explained variation (fraction $\mathrm{c}=$ these fishes into the estuary. Juveniles of mullets $M$. gaimardianus and $M$. curema were abundant in the estuary from January-February to March-April, whereas juveniles of mullet $M$. liza and whitemouth croaker occurred year-round in the estuary (Fig. 2). In contrast, the Argentine menhaden had no significant correlation with PC-20, as indicated by the vector representing this species not being circumscribed by either of the 2 Van Dobben circles (Fig. 8). Other temporal descriptors with similar annual cycles (PC$41,25,21,23,19$, and 15, ranging from 0.5 to $1.3 \mathrm{yr}$ ) also made significant contributions to the model, and together accounted for an additional $37.7 \%$ of total explained variation (Table 2). These temporal de- 


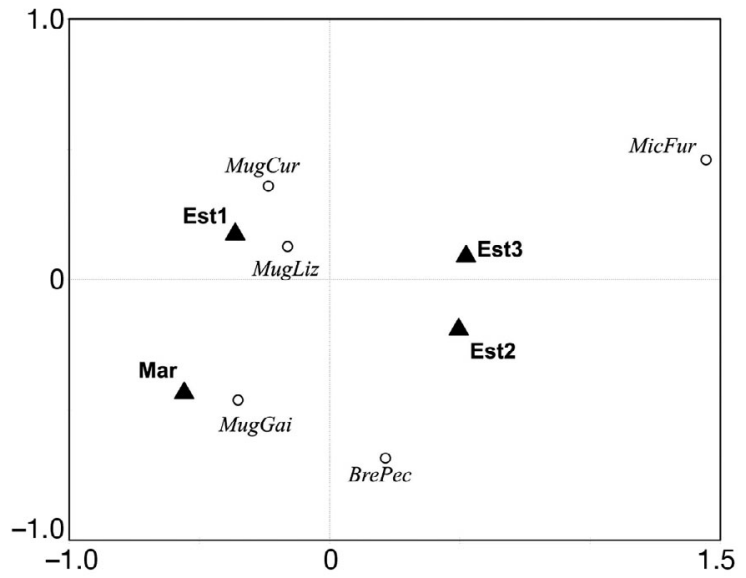

Fig. 6. Canonical Correspondence Analysis (CCA) ordination plot showing the association of fish species abundance across different sampling sites in the study area. Association of species with each axis is represented by its score (plotted) and correlation between sampling sites (nominal variables denoted by triangles) and axes are represented by their position relative to each canonical axis. (o) Fish species (abbreviations in Fig. 5). (ム) Sample sites: Mar: marine adjacent area; Est1, Est2, Est3: estuarine sites

scriptors operated at slightly shorter or longer scales than the annual cycle depicted by PC-20, but they were either out of phase or in opposition with each other.

Inter-annual variation (temporal scales from 2.3 to $10.5 \mathrm{yr})$, although accounting for less total variation in fish abundance $(39.1 \%)$, was significant, particularly the temporal descriptors PC-1 (10.5 yr period) that alone modeled $12.3 \%$ of explained variation in fish abundance (Table 2). Correlations between abundance of individual fish species with these interannual temporal descriptors varied (Fig. 8). For instance, the Argentine menhaden and the mullet Mugil curema were positively correlated with the large fluctuation depicted by PC-1, showing significantly lower catches in the first half of the sampling period and a subsequent increase in the remaining years (Figs. 3 \& 8). In contrast, the whitemouth croaker and the mullet $M$. gaimardianus were negatively correlated with PC-1 (Fig. 8), with higher abundances during the first half and lower abundances during the second half of the study period (Fig. 3). The mullet $M$. liza had no significant correlation with the $\sim 10$ yr period represented by PC-1.

Between the annual and decadal fluctuations, it was possible to identify other significant fluctuations of 3.5 (PC-5) and 7.0 (PC-2) yr, accounting for 6.7 and $9.2 \%$, respectively, of the explained variation in fish species abundance (Table 2). Mullets and the whitemouth croaker were the only species showing signif- icant relationships with these fluctuations (Fig. 8). Mullets Mugil curema and M. gaimardianus were positively correlated ( $t$-values $>0$ and $<+2$ ) with the $7 \mathrm{yr}$ temporal fluctuation, whereas abundances of the other mullet, M. liza, and the whitemouth croaker were negatively correlated with this trend ( $t$-values $<0$ and $>-2$ ). The only species showing a correlation with the $3.5 \mathrm{yr}$ fluctuation was the mullet $M$. curema (Fig. 8).

\section{DISCUSSION}

\section{Spatial versus temporal dimensions}

Our results showed that rainfall, temperature and salinity explained $22.4 \%$ of the variation in abundance of marine estuarine-dependent fishes occurring in Patos Lagoon Estuary. Prior studies in this estuary have already discussed the relevance of these environmental variables in explaining fish

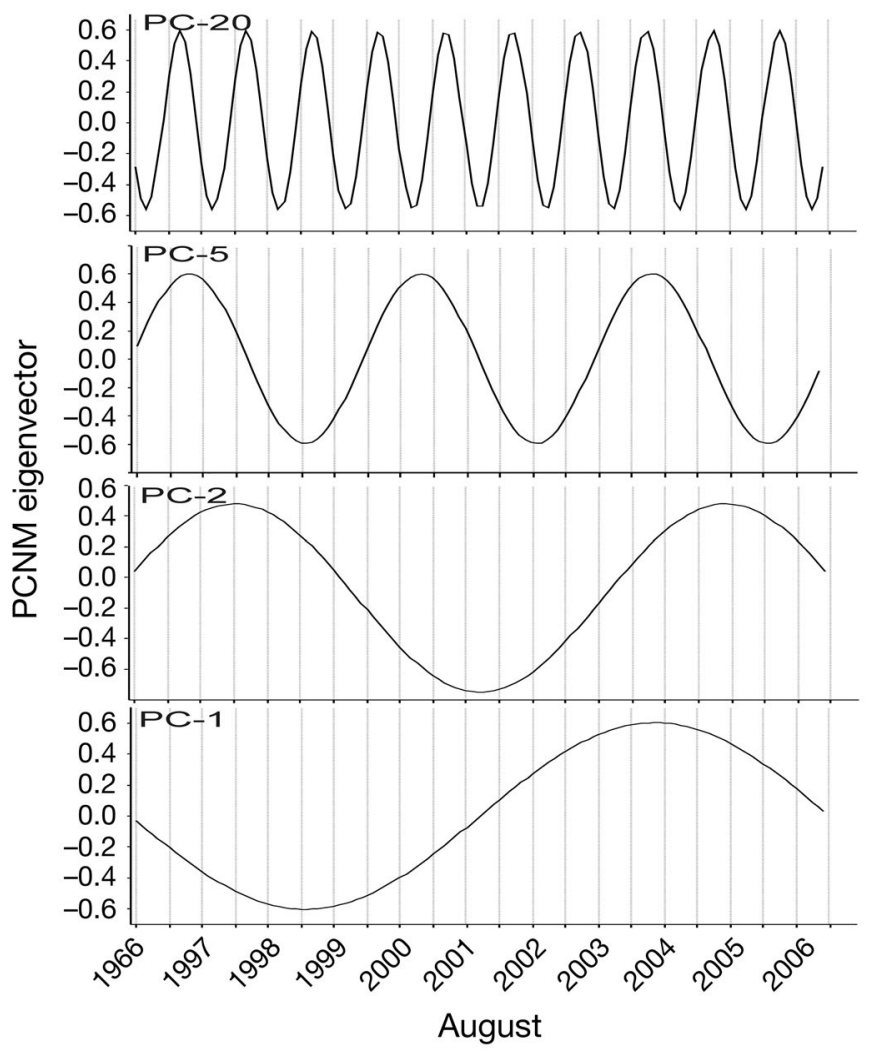

Fig. 7. Temporal fluctuation patterns of selected principal coordinates of neighbor matrix (PCNM) eigenvectors associated with annual (PC-20) and inter-annual variation (PC-5, $\mathrm{PC}-2, \mathrm{PC}-1)$ of the abundance of the studied marine estuarine-dependent fishes species in Patos Lagoon Estuary from August 1996 to January 2007 

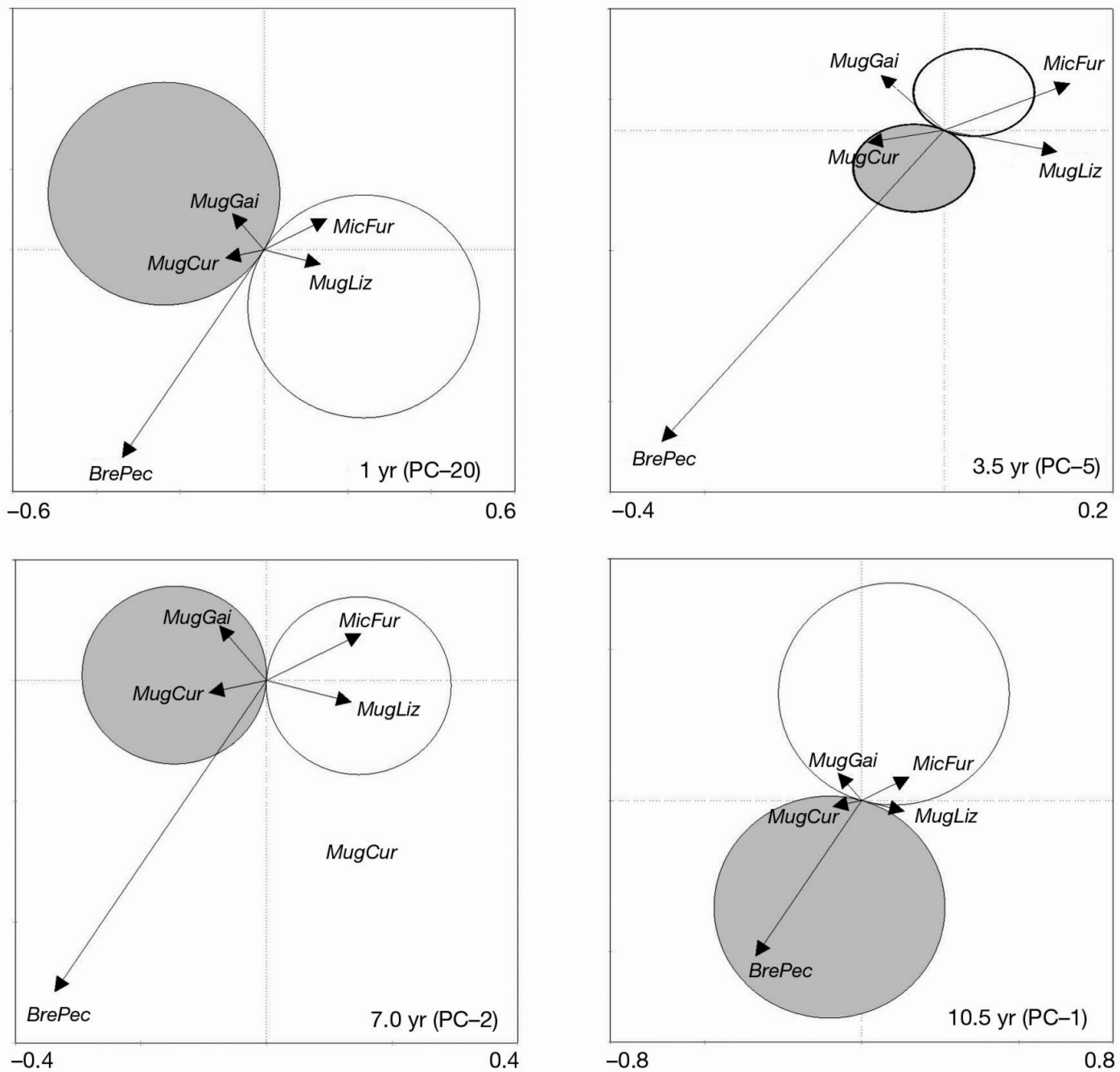

Fig. 8. Bi-plots of $t$-values with Van Dobben circles showing pair-wise relationships between each fish species and temporal descriptors: PC-20 (1 yr fluctuation period), PC-5 (3.5 yr), PC-2 (7 yr) and PC-1 (10.5 yr). Those vectors with arrowheads ending inside the circles have statistically significant pair-wise relationships with the assigned explanatory variables $(t$-value regression coefficients between -2 and +2 ). Gray and white circles denote positive and negative relationships, respectively. See

Fig. 5 for abbreviations

abundance (Garcia et al. 2001, 2003a, 2004a). However, the predominant modes of variation in fish abundance in this system were unknown and our analytical approach, combining partition variation associated with a multivariate time series analysis, substantially contributed to advance our understanding in this area. After factoring out common spatiotemporal variation $(0.8 \%)$, our partitioning analysis showed that the temporal dimension (after controlling the variation related to spatial scale) had an almost 5 -fold greater contribution $(28.0 \%)$ than the spatial scale $(6.4 \%)$ in explaining variation in abundance of marine estuarine-dependent fishes recruiting to a subtropical Western Atlantic estuary.
Moreover, we found that most of the temporal variation $(58.5 \%)$ was associated with annual (0.5 to $1.3 \mathrm{yr}$ ) rather than multi-year $(>2 \mathrm{yr})$ patterns of fluctuation.

Relatively low spatial variation in the abundance of marine estuarine-dependent fishes in Patos Lagoon Estuary could be explained by the species' tolerance of a broad range of salinities (Chao et al. 1985). These euryhaline species are widespread along the marineestuarine gradient of this region (Chao et al. 1985, Vieira et al. 2010), with most spawning in the sea and their juveniles particularly abundant in shallow waters $(<1.5 \mathrm{~m})$ of the estuary (Chao et al. 1985, Vieira et al. 2010, Becker et al. 2011), where food is 
abundant (Figueiredo \& Vieira 2005, Rosa \& Bemvenuti 2006, Mendoza-Carranza \& Vieira 2008, Vieira et al. 2010). The marine estuarine-dependent species studied are commonly found between the Patos Lagoon Estuary and adjacent marine areas probably because salinity differences between these systems does not constitute a physiological barrier to these euryhaline species. This may partially explain why the spatial scale had a lower contribution to the explanation of variation in abundance of marine estuarine-dependent fishes recruiting into this estuary.

The annual patterns of variation that dominated our analysis of fish abundance are probably associated with evolutionary adaptations of these marine estuarine-dependent fishes to exploit predictable seasonal pulses of aquatic primary and secondary production that commonly occur in temperate and subtropical estuaries. Seasonality in solar irradiance and temperature in these mid-latitudes drive peaks of productivity during spring and summer and lower production during late fall and winter (Day et al. 1989, Murrell \& Lores 2004, Strydom \& d'Hotman 2005, Jeong et al. 2009). Long-term ecological studies carried out in Patos Lagoon Estuary clearly show such seasonal pulses in both primary and secondary production (Seeliger et al. 1997, Abreu et al. 2010, Seeliger \& Odebrecht 2010). Water temperature variation in this region is typical of warm temperate systems, with lowest values $\left(10\right.$ to $\left.15^{\circ} \mathrm{C}\right)$ during the austral winter (July) and highest temperatures from January to March $\left(22\right.$ to $30^{\circ} \mathrm{C}$ ) (Odebrecht et al. 2010). Accordingly, chlorophyll a concentrations increase in spring (10 to $70 \mu \mathrm{g} \mathrm{l}^{-1}$ ) and high values are common in the estuary throughout the summer, especially due to growth of diatoms (Fujita \& Odebrecht 2007). Seagrass beds (dominated by the widgeon grass Ruppia maritima) and macroalgae (e.g. Ulva spp., Cladophora spp., Rhizoclonium riparium) also make significant contributions to seasonal production in this system, with biomass production ranging from 50 to $300 \mathrm{~g}$ dry wt $\mathrm{m}^{-2}$ (seagrass) and 0.5 to 1.2 $\mathrm{C} \mathrm{m}^{-2} \mathrm{yr}^{-1}$ (macroalgae) (Coutinho \& Seeliger 1986, da Silva \& Asmus 2001). This seasonal production sustains an array of micro- and macro-consumers, especially decapod crustaceans and fishes (Rosa \& Bemvenuti 2006, Odebrecht et al. 2010, Vieira et al. 2010). Consequently, patterns of abundance of primary producers and estuarine fishes in Patos Lagoon covary on an intra-annual scale.

Coupling of producer and consumer biomass has been recognized in estuaries and pelagic oceanic waters of temperate latitudes of the Atlantic Ocean
(Strydom \& d'Hotman 2005, Haynes et al. 2010, Kristiansen et al. 2011). Our temporal analysis based on PCNM, however, suggests that such annual cycles in abundance of marine estuarine-dependent fishes are more complex than relationships portrayed in previous studies (Chao et al. 1985, Vieira 1991, Garcia \& Vieira 1997, Vieira et al. 1998). Instead of a regular intra-annual seasonal cycle, annual abundance of marine estuarine-dependent fishes at Patos Lagoon reveals cycles with distinct peaks that occur every 0.5 to $1.3 \mathrm{yr}$. Differences in amplitude among these annual peaks are probably modulated by conspicuous short-term (from hours to months) variability in physicochemical parameters (e.g. salinity, turbidity) and their effects on primary and secondary production. Other abiotic factors that strongly influence movements of juvenile marine migrant fishes between the sea and estuary, such as wind patterns and freshwater discharge, could reduce or increase the periodicity of abundance peaks. For instance, the mullet Mugil liza spawns in the sea and postlarvae $(<50 \mathrm{~mm})$ are transported into the estuary by a net upstream circulation near the bottom of the water column at the estuary mouth. Recruits remain in shallow waters of the estuary until maturation and then migrate, usually during April and May, towards offshore spawning grounds (Vieira 1991). A sudden drop in water temperature $\left(<19^{\circ} \mathrm{C}\right)$ and intrusion of marine waters into the estuary seem to trigger spawning migrations (Vieira \& Scalabrin 1991). Therefore, differences in the onset of these environmental cues (e.g. delay in the intrusion of salinity waters into the estuary during El Niño events; Vieira et al. 2008) could delay or hinder migration towards the sea, thereby altering their residence time within the estuary and, consequently, temporal abundance patterns.

\section{Multi-year variation}

Although to a lesser extent than the annual scale, inter-annual scales from 2.3 to $10.5 \mathrm{yr}$ were also significant in modeling fish abundance in Patos Lagoon. Previous long-term studies in this estuarine system have shown that such multi-year variation in fish abundance is strongly linked to climatological and hydrological effects trigged by the ENSO phenomenon (Garcia et al. 2001, 2003a,b, 2004a, Vieira et al. 2008). Positive and negative rainfall anomalies in the drainage basin of Patos Lagoon $\left(200000 \mathrm{~km}^{2}\right)$ are associated with El Niño and La Niña episodes, respectively (Grimm et al. 1998, 2000). Such anom- 
alies seem to modulate the diversity and abundance patterns of several taxa in Patos Lagoon Estuary and the adjacent marine area (Odebrecht et al. 2010). For instance, the high rainfall associated with strong El Niño events produces freshwater outflow anomalies (from $2400 \mathrm{~m}^{3} \mathrm{~s}^{-1}$ to $12000 \mathrm{~m}^{3} \mathrm{~s}^{-1}$ ) that flush freshwater species into the lower portion of the estuarine zone (Garcia et al. 2003b). At the same time, such high freshwater outflow acts as a physical barrier for larvae and juveniles of marine-spawning species, such as pink shrimp Farfantepenaeus paulensis (Möller et al. 2009) and mullets (Garcia et al. 2004a), that seek to enter the estuary to complete their life cycles. The opposite pattern is found during La Niña events, when negative rainfall anomalies cause lower freshwater outflow and greater intrusion of seawater into the estuary. This condition favors the entrance of larvae and post-larvae of marine-spawning species into the estuary and, consequently, potential for enhanced recruitment of marine migrant fishes (Grimm et al. 1998, Martins et al. 2007, Vieira et al. 2008, Möller et al. 2009, Muelbert et al. 2010). Thus, the observed inter-annual patterns of variation in marine estuarine-dependent fish abundance occurring from 3.5 to $7.0 \mathrm{yr}$ are probably related to ENSO events reported to occur with a similar periodicity (Rodbell et al. 1999, Glantz 2001). Therefore, a large fraction (18.7\%) of the explained variation in the inter-annual abundance of marine estuarine-dependent fishes in Patos Lagoon could be attributed to the influence of the ENSO.

Our analysis also revealed that a significant fraction of inter-annual variation in the abundance of marine estuarine-dependent fishes occurred at approximately 2 yr (e.g. PC-8: 2.3 yr and PC-7: 2.6 yr) and $10 \mathrm{yr}$ (e.g. PC-1) time scales, which accounted for $8.1 \%$ (considering both PC- 8 and PC-7) and $12.3 \%$ of the explained variance, respectively. Variation in the larger scale ( $10 \mathrm{yr})$ was most apparent in the Argentine menhaden. According to Legendre \& Legendre (1998), an event or pattern needs to be observed at least twice in order to draw inferences about temporal dynamics. Therefore, a larger data set would be needed in order to determine the real importance of this $\sim 10$ yr cycle in fish abundance. The shorter 2 yr scale could not be attributed to the ENSO, which is reported to occur with a distinct frequency in the Equatorial Pacific Ocean (Rodbell et al. 1999, Glantz 2001). Rather, we speculated that 2 yr fluctuations in estuarine-dependent fish abundance could be linked to other temperate-zone meteorological phenomena. For example, a climatic phenomenon known as the Southern Annular Mode (SAM) oscillates with a period of about 2 yr. Spectral analysis using SAM index time-series (1996 to 2010) shows significant periodic cycles of $2.21 \mathrm{yr}$, and SAM has been associated with large-scale climatic variability in middle and higher latitudes of the Southern Hemisphere (Hendon et al. 2007). This climatic phenomenon conventionally refers to oscillations of sea level pressure in the Southern Hemisphere, especially between polar regions and middle latitudes (Limpasuvan \& Hartmann 1999, Oke \& England 2004). The SAM phenomenon seems to influence rainfall patterns and the occurrence of storms and cyclones in South America, Africa and Australia through its connection with atmospheric components, such as latitudinal migration shifts of the subtropical upper-level jet, variations in the intensity of the polar jet, and fluctuations in the subpolar westerly winds (Rao et al. 2003, Carvalho et al. 2005, Harry et al. 2006, Hendon et al. 2007, Nicholls 2010, Sun et al. 2010). SAM has been also linked with ocean circulation around the South Pole (Rintoul \& England 2002, Oke \& England 2004), with potential effects on water circulation and biological production in the Subtropical Convergence Zone. Patos Lagoon is located under the influence of this important convergence zone (Seeliger et al. 1997), and, as noted previously, wind and rainfall regimes influence the abundance of aquatic organisms in Patos Lagoon (Garcia et al. 2001, 2003a, 2004a, Martins et al. 2007, Möller et al. 2009, Odebrecht et al. 2010). It seems plausible, therefore, that such large-scale phenomenon affecting atmospheric and oceanographic conditions in the South Atlantic with approximately a $2 \mathrm{yr}$ frequency would play a role in the post-spawning success of marine migrant species that use the Patos Lagoon Estuary as a nursery. The current study supports findings from several prior studies that demonstrated the influence of large-scale coupled ocean-atmosphere phenomena in the Pacific Ocean (ENSO) on the estuarine fish assemblage inhabiting the Southwestern Atlantic Coast of Brazil (Garcia et al. 2001, 2003a, Vieira et al. 2008, Dumont \& D'Incao 2011). The influence of similar coupled ocean-atmosphere phenomena, such as the SAM, on inter-annual variation of estuarinedependent fishes and other marine taxa in this region and elsewhere deserves further investigation.

In summary, our $10 \mathrm{yr}$ data set of continuous and standardized monthly time series revealed that 5 marine-spawning fishes ( 3 species of mullets, Argentine menhaden, and whitemouth croaker) recruiting into a subtropical Western Atlantic estuary showed marked annual and inter-annual variation in their relative abundance. Temperature had a regular sea- 
sonal pattern in this system, with lowest values $\left(11.5^{\circ} \mathrm{C}\right)$ during winter and highest values $\left(26.5^{\circ} \mathrm{C}\right)$ during summer, which contrasted with the strong intra- and inter-annual variation observed in salinity and rainfall. These environmental variables explained $22.4 \%$ of the variation in fish abundance. More importantly, our partition variance analysis revealed that variation in species abundance was almost 5-fold higher across the temporal (28\%) than the spatial scale $(6.4 \%)$. The colinearity between these scales was minimal $(0.8 \%)$ and there was a considerable amount of fish abundance variation $(64.8 \%)$ that could not be explained by these spatial or temporal components. The temporal variation occurred mainly at annual (0.5 to $1.3 \mathrm{yr}$ ) and interannual (2.3 to $10.5 \mathrm{yr}$ ) scales, which accounted for 58.5 and $39.1 \%$ of the explained temporal variation in fish species abundance, respectively. We hypothesized that the prevalence of annual modes of variation in these marine estuarine-dependent fishes are probably associated with adaptations for exploiting predictable seasonal productivity pulses typically found in this subtropical estuary. In contrast, interannual variation in abundance could be attributed to the influence of large-scale climatic phenomena. For instance, positive and negative anomalies of rainfall and salinity triggered by strong ENSO events have marked influence in the ichthyofauna of this estuary (Garcia et al. 2004a) and could explain fish abundance variations at the 3 to 7 yr scale. We also speculated that another large-scale climatic phenomenon, the Southern Annular Mode (SAM), could be associated with variations in fish abundance at intermediate (2 yr) temporal scales.

Acknowledgements. The study received financial support from the Conselho Nacional de Desenvolvimento Científico e Tecnológico - CNPq (Brazil), Brazilian Long Term Ecological Research (B-LTER) and the Inter American Institute for Global Change Research (IAI) through a fellowship granted by SACC/Consortium (CRN-2076).

\section{LITERATURE CITED}

Able KW (2005) A re-examination of fish estuarine dependence: evidence for connectivity between estuarine and ocean habitats. Estuar Coast Shelf Sci 64:5-17

> Abreu PC, Bergesch M, Proença LA, Garcia CAE, Odebrecht C (2010) Short- and long-term chlorophyll a variability in the shallow microtidal Patos Lagoon Estuary, Southern Brazil. Estuaries Coasts 33:554-569

> Akin S, Buhan E, Winemiller KO, Yimaz H (2005) Fish assemblage structure of Koycegiz Lagoon-Estuary, Turkey: spatial and temporal distribution patterns in relation to environmental variation. Estuar Coast Shelf Sci 64:671-684
Ambrose RF, Meffert DJ (1999) Fish-assemblage dynamics in Malibu Lagoon, a small, hydrologically altered estuary in southern California. Wetlands 19:327-340

Asmus ML (1997) Coastal plain and Patos Lagoon. In: Seeliger U, Odebrecht C, Castello JP (eds) Subtropical convergence environments: the coast and sea in the Southwestern Atlantic. Springer, Berlin, p 9-12

Becker AG, Gonçalves JF, Toledo JA, Burns MDM, Garcia LO, Vieira JP, Baldisserotto B (2011) Plasma ion levels of freshwater and marine/estuarine teleosts from Southern Brazil. Neotrop Ichthyol 9:895-900

Bemvenuti MA (1987) Abundância, distribuição e reprodução de peixes-rei (Atherinidae) na região estuarina da Lagoa dos Patos, RS, Brasil. Atlantica 9:5-32

> Bertolo A, Magnan P (2006) Spatial and environmental correlates of fish community structure in Canadian Shield lakes. Can J Fish Aquat Sci 63:2780-2792

Borcard D, Legendre P (2002) All-scale spatial analysis of ecological data by means of principal coordinates of neighbor matrices. Ecol Model 153:51-68

Borcard D, Legendre P (2004) SpaceMaker2-User's guide. Département de Sciences Biologiques, Université de Montréal, Montréal

Borcard D, Legendre P, Drapeau P (1992) Partialling out the spatial component of ecological variation. Ecology 73: 1045-1055

Borcard D, Legendre P, Avois-Jacquet C, Tuomisto H (2004) Dissecting the spatial structure of ecological data at multiple scales. Ecology 85:1826-1832

Calliari LJ, Griep G, Vieira H (1977) Sedimentologic characteristics of the second profile of benthos-Lagoa dos Patos-southern portion. Atlantica 2:63-82 (in Portuguese)

Carvalho LMV, Jones C, Ambrizzi T (2005) Opposite phases of the Antarctic Oscillation and relationships with intraseasonal to interannual activity in the Tropics during the austral summer. J Clim 18:702-718

Chao LH, Pereira LE, Vieira JP (1985) Estuarine fish community of the Patos Lagoon, Brazil: a baseline study. In: Yáñez-Arancibia A (ed) Fish community ecology in estuaries and coastal lagoons: towards an ecosystem integration. Universidad Nacional Autónoma de México Press, Mexico City, p 429-450

Costa CSB, Seeliger U, Oliveira CPL, Mazo AMM (1997) Distribuição, funções e valores das marismas e pradarias submersas no estuário da Lagoa dos Patos (RS, Brasil). Atlantica 19:67-85

> Coutinho R, Seeliger U (1986) Seasonal occurrence and growth of benthic algae in the Patos Lagoon estuary, Brazil. Estuar Coast Shelf Sci 23:889-900

Day JWJr, Hall CAS, Kemp WM, Yáñez-Arancibia A (1989) Estuarine ecology. John Wiley \& Sons, New York, NY

> Dumont LFC, D'Incao F (2011) By-catch analysis of Argentinean prawn Artemesia longinaris (Decapoda: Penaeidae) in surrounding area of Patos Lagoon, southern Brazil: effects of different rainfall. J Mar Biol Assoc UK 91:1059-1072

> Figueiredo GM, Vieira JP (2005) Diel feeding, daily food consumption and the predatory impact of whitemouth croaker (Micropogonias furnieri) in an estuarine environment. PSZN I: Mar Ecol 26:130-139

Fujita CCY, Odebrecht C (2007) Short term variability of chlorophyll $a$ and phytoplankton composition in a shallow area of the Patos Lagoon estuary (Southern Brazil). Atlantica 29:93-107 
Garcia AM, Vieira JP (1997) Abundância e diversidade da assembléia de peixes dentro e fora de uma pradaria de Ruppia maritima L., no estuário da Lagoa dos Patos (RSBrasil). Atlantica 19:161-182

Garcia AM, Vieira JP, Winemiller KO (2001) Dynamics of the shallow-water fish assemblage of the Patos Lagoon estuary (Brazil) during cold and warm ENSO episodes. J Fish Biol 59:1218-1238

Garcia AM, Vieira JP, Winemiller KO (2003a) Effects of 1997-1998 El Niño on the dynamics of the shallow-water fish assemblage of the Patos Lagoon Estuary (Brazil). Estuar Coast Shelf Sci 57:489-500

> Garcia AM, Raseira MB, Vieira JP, Winemiller KO, Grimm AM (2003b) Spatiotemporal variation in shallow-water freshwater fish distribution and abundance in a large subtropical coastal lagoon. Environ Biol Fishes 68: 215-228

- Garcia AM, Vieira JP, Winemiller KO, Grimm AM (2004a) Comparison of the 1982-1983 and 1997-1998 El Niño effects on the shallow-water fish assemblage of the Patos Lagoon estuary (Brazil). Estuaries 27:905-914

> Garcia AM, Vieira JP, Winemiller KO, Raseira MO (2004b) Reproductive cycle and spatiotemporal variation in abundance of the one-sided livebearer Jenynsia multidentata, in Patos Lagoon, Brazil. Hydrobiologia 515: $39-48$

Glantz MH (2001) Currents of change: impacts of El Niño and La Niña on climate and society, 2nd edn. Cambridge University Press, Cambridge

González Castro M, Díaz de Astarloa JM, Cousseau MB, Figueroa DE and others (2009) Fish composition in a south-western Atlantic temperate coastal lagoon: spatial-temporal variation and relationships with environmental variables. J Mar Biol Assoc UK 89:593-604

Gordo LS, Cabral HN (2001) The fish assemblage structure of a hydrologically altered coastal lagoon: the Óbidos lagoon (Portugal). Hydrobiologia 459:125-133

$>$ Greenwood MFD (2007) Nekton community change along estuarine salinity gradients: Can salinity zones be defined? Estuaries Coasts 30:537-542

> Grimm AM, Ferraz SET, Gomes J (1998) Precipitation anomalies in southern Brazil associated with El Niño and La Niña events. J Clim 11:2863-2880

Grimm AM, Barros VR, Doyle ME (2000) Climate variability in southern South America associated with El Niño and La Niña events. J Clim 13:35-58

Haimovici M, Martins AS, Vieira PC (1996) Distribuição e abundância de peixes teleósteos demersais sobre a plataforma continental do sul do Brasil. Rev Bras Biol 56: 27-50

> Haynes PS, Brophy D, McGrath D, O'Callaghan R, Comerford S, Casburn P (2010) Annual and spatial variation in the abundance length and condition of juvenile turbot (Psetta maxima L.) on nursery grounds on the west coast of Ireland: 2000-2007. J Sea Res 64:494-504

> Hendon HH, Thompson DWJ, Wheeler MC (2007) Australian rainfall and surface temperature variations associated with the Southern Hemisphere annular mode. J Clim 20:2452-2467

Herrell AM, Methven DA (2009) Annual and monthly variation in species composition and catches of fishes from the Tabusintac River Estuary in the southern Gulf of St. Lawrence. Can Field Nat 123:48-67

> James NC, Whitfield AK, Cowley PD (2008) Long-term stability of the fish assemblages in a warm-temperate South
African estuary. Estuar Coast Shelf Sci 76:723-738

> Jeong SJ, Yu OH, Suh HL (2009) Reproductive patterns and secondary production of Gammaropsis japonicus (Crustacea, Amphipoda) on the seagrass Zostera marina of Korea. Hydrobiologia 623:63-76

Kjerfve B (1986) Comparative oceanography of coastal lagoons. In: Wolfe DA (ed) Estuarine variability. Academic Press, New York, NY, p 63-82

Kristiansen T, Drinkwater KF, Lough RG, Sundby S (2011) Recruitment variability in North Atlantic cod and matchmismatch dynamics. PLoS ONE 6:e17456

> Legendre P (2008) Studying beta diversity: ecological variation partitioning by multiple regression and canonical analysis. J Plant Ecol 1:3-8

Legendre P, Legendre L (1998) Numerical ecology, 2nd edn. Elsevier Science, Amsterdam

Lepš J, Šmilauer P (2003) Multivariate analysis of ecological data using CANOCO. Cambridge University Press, New York, NY

Limpasuvan V, Hartmann DL (1999) Eddies and the annular modes of climate variability. Geophys Res Lett 26: 3133-3136

> Love JW, Chigbu P, May EB (2009) Environmental variability affects distributions of coastal fish species (Maryland). Northeast Nat 16:255-268

Martinho F, Dolbeth M, Viegas I, Teixeira CM, Cabral HN, Pardal MA (2009) Environmental effects on the recruitment variability of nursery species. Estuar Coast Shelf Sci 83:460-468

Martino EJ, Able KW (2003) Fish assemblages across the marine to low salinity transition zone of a temperate estuary. Estuar Coast Shelf Sci 56:969-987

> Martins IM, Dias JM, Fernandes EH, Muelbert JH (2007) Numerical modelling of fish eggs dispersion at the Patos Lagoon estuary - Brazil. J Mar Syst 68:537-555

Mendoza-Carranza M, Vieira JP (2008) Whitemouth croaker Micropogonias furnieri (Desmarest, 1823) feeding strategies across four southern Brazilian estuaries. Aquat Ecol 42:83-93

> Möller OO, Castaing P, Salomon JC, Lazure P (2001) The influence of local and non-local forcing effects on the subtidal circulation of the Patos Lagoon. Estuaries 24: 297-311

Möller OO, Castello JP, Vaz AC (2009) The effect of river discharge and winds on the interannual variability of the pink shrimp Farfantepenaeus paulensis production in Patos Lagoon. Estuaries Coasts 32:787-796

Muelbert JH, Muxagata E, Kaminski SM (2010) As comunidades zooplanctônicas. In: Seeliger U, Odebrecht C (eds) O Estuário da Lagos dos Patos: um século de transformações. Editora da FURG, Rio Grande, p 67-75

Murrell MC, Lores EM (2004) Phytoplankton and zooplankton seasonal dynamics in a subtropical estuary: importance of cyanobacteria. J Plankton Res 26:371-382

> Nicholls N (2010) Local and remote causes of the southern Australian autumn-winter rainfall decline, 1958-2007. Clim Dyn 34:835-845

Odebrecht C, Abreu PC, Bemvenuti CE, Copertino M, Muelbert JH, Vieira JP, Seeliger U (2010) The Patos Lagoon Estuary: biotic responses to natural and anthropogenic impacts in the last decades (1979-2008). In: Kennish MJ, Paerl H (eds) Coastal lagoons: critical habitats of environmental change. Taylor \& Francis/CRC Press, Boca Raton, FL, p 437-459

Oke PR, England MH (2004) Oceanic response to changes in 
the latitude of the Southern Hemisphere subpolar westerly winds. J Clim 17:1040-1054

Peres-Neto PR (2006) A unified strategy for estimating and controlling spatial, temporal and phylogenetic autocorrelation in ecological models. Oecol Bras 10:105-119

Peres-Neto PR, Legendre P, Dray S, Borcard D (2006) Variation partitioning of species data matrices: estimation and comparison of fractions. Ecology 87:2614-2625

Pérez-Ruzafa A, Marcos C, Pérez-Ruzafa IM, Barcala E, Hegazi MI, Quispe J (2007) Detecting changes resulting from human pressure in a naturally quick-changing and heterogeneous environment: spatial and temporal scales of variability in coastal lagoons. Estuar Coast Shelf Sci 75:175-188

Plavan AA, Passadore C, Gimenez L (2010) Fish assemblage in a temperate estuary on the Uruguayan coast: seasonal variation and environmental influence. Braz J Oceanogr 58:299-314

Power M, Attrill MJ, Thomas RM (2000) Temporal abundance patterns and growth of juvenile herring and sprat from the Thames estuary 1977-1992. J Fish Biol 56: 1408-1426

Rao VB, do Carmo AMC, Franchito SH (2003) Interannual variations of storm tracks in the Southern Hemisphere and their connections with the Antarctic Oscillation. Int J Climatol 23:1537-1545

> Reis EG, D'Incao F (2000) The present status of artisanal fisheries of extreme Southern Brazil: an effort towards community-based management. Ocean Coast Manag 43: 585-595

Reum JCP, Essington TE, Greene CM, Rice CA, Fresh KL (2011) Multiscale influence of climate on estuarine populations of forage fish: the role of coastal upwelling, freshwater flow and temperature. Mar Ecol Prog Ser 425: 203-215

Rintoul SR, England MH (2002) Ekman transport dominates local air-sea fluxes in driving variability of Subantarctic Mode Water. J Phys Oceanogr 32:1308-1321

Rodbell DT, Seltzer GO, Anderson DM, Abbott MB, Enfield DB, Newman JH (1999) An 15,000-year record of El Niño-driven alluviation in southwestern Ecuador. Science 283:516-520

Rosa LC, Bemvenuti CE (2006) Temporal variability of the estuarine macrofauna of the Patos Lagoon, Brazil. Rev Biol Mar Oceanogr 41:1-9</ jrn>

Seeliger U, Odebrecht C (2010) (eds) O Estuário da Lagos dos Patos: um século de transformações. Editora da FURG, Rio Grande

Seeliger U, Odebrecht C, Castello JP (1997) Subtropical convergence environments: the coast and sea in the southwestern Atlantic. Springer-Verlag, Berlin da Silva ET, Asmus ML (2001) A dynamic simulation model of the widgeon grass Ruppia marítima and its epiphytes in the estuary of the Patos Lagoon, RS, Brazil. Ecol Modell 137:161-179

- Sosa-López A, Mouillot D, Ramos-Miranda J, Flores-Hernandez D, Chi TD (2007) Fish species richness decreases with salinity in tropical coastal lagoons. J Biogeogr 34: 52-61

Strydom NA, d'Hotman BD (2005) Estuary-dependence of larval fishes in a non-estuary associated South African surf zone: evidence for continuity of surf assemblages. Estuar Coast Shelf Sci 63:101-108

Sun QJ, Wang HJ, Yuan W (2010) Linkage of the boreal apring Antarctic Oscillation to the West African summer monsoon. J Meteorol Soc Jpn 88:15-28

ter Braak CJF (1986) Canonical correspondence analysis: a new eigenvector technique for multivariate direct gradient analysis. Ecology 67:1167-1179

ter Braak CJF, Looman CWN (1994) Biplots in reduced-rank regression. Biom J 36:983-1003

ter Braak CJF, Šmilauer P (2002) CANOCO Reference manual and CanoDraw for Windows user's guide: software for canonical community ordination (version 4.5). Microcomputer Power, Ithaca, NY

- Upchurch S, Wenner E (2008) Fish and decapod crustacean assemblages from the Ashepoo-Combahee-Edisto Basin, South Carolina (1993-1999). J Coast Res 55:200-213

> Vieira JP (1991) Juvenile mullets (Pisces: Mugilidae) in the Estuary of Lagoa dos Patos, RS, Brazil. Copeia 1991: 409-418

Vieira JP, Castello JP (1997) Fish fauna. In: Seeliger U, Odebrecht C, Castello JP (eds) Subtropical convergence environments: the coast and sea in the southwestern Atlantic. Spring-Verlag, New York, NY

Vieira JP, Scalabrin C (1991) Migração reprodutiva da tainha (Mugil platanus, Günter, 1880) no litoral sud do Brasil. Atlantica 13:131-141

Vieira JP, Castello JP, Pereira LE (1998) Ictiofauna. In: Seelinger U, Odebrecht C, Castello JP (eds) Os ecosistemas costeiro e marinho do extremo sul do Brasil. Ecosciencia, Rio Grande

Vieira JP, Garcia AM, Grimm AM (2008) Evidences of El Niño effects on the mullet fishery of the Patos Lagoon estuary. Braz Arch Biol Technol 51:433-440

Vieira JP, Garcia AM, Moraes LE (2010) A assembléia de peixes. In: Seeliger U, Odebrecht C (eds) O Estuário da Lagos dos Patos: um século de transformações. Editora da FURG, Rio Grande, p 79-90

Whitfield AK (1996) A review of factors influencing fish utilization of South African estuaries. Trans R Soc S Afr 51:115-137

Submitted: September 12, 2011; Accepted: April 11, 2012 Proofs received from author(s): July 24, 2012 